\title{
Cherkashyna V. ADJUSTMENT OF AIR LINE STRUCTURE FOR OPTIMAL TRANSPORT MANAGEMENT AND ELECTRICITY DISTRIBUTION
}

Об’єктом дослідження є процеси в повітряних лініях, які впливають на транспортування $і$ розподіл електроенергї. Одним з найбільш проблемних місць є провода повітряних ліній. Різноманіття проводів, якими виконані лінї, призводить до неоднорідності мережі, що відображається на технологічних втратах потужності.

В ході дослідження використовувалася техніко-економічна модель дисконтованих витрат в повітряних лініях, яка була вдосконалена за рахунок зміни аналітичного зв'язку інвестичій з перерізом проводу. Для аналізу даної моделі використовувався критеріальний метод. Даний метод дозволяє проводити аналіз таких моделей і прийняти рішення в відносних одинииях при неповній вихідній інформацї.

Отримано, що вдосконалення структури повітряних ліній за рахунок оптимізачї параметричних рядів перерізів проводів дозволяє зменшити вплив неоднорідності мережі. А також перейти до уніфікаиї повітряних ліній, збільшити регламент реконструкцї об’єкта, але не розширює функціональні можливості ліній.

Оснащення ліній волоконно-оптичною системою моніторингу дозволяє контролювати параметри об'єкта по всій довжині об'єкта. Завдяки цьому зменшуються втрати активної потужності $і$ забезпечується можливість оптимального керування транспортуванням і розподіленням електроенергї в реальному часі.

Запропонований напрямок має ряд особливостей, зокрема показує послідовне вдосконалення структури ліній. У порівнянні з аналогічними відомими підходами перевагою запропонованого підходу є комплексне обгрунтування розвитку повітряних ліній в умовах ринку електроенергї.

Ключові слова: електрична мережа, повітряна лінія, параметричний ряд, система моніторингу, техніко-економічна модель, критеріальний метод.

\section{Introduction}

In the electricity market, «intelligent» networks occupy a central place among energy-efficient developments. These networks represent the power grid complex, which is based on modern technologies. For the operation of «smart» networks, it is necessary to improve the structure of electrical networks (EN) and to provide integrated management of all technological processes, including the electricity transportation.

At the same time, special attention should be paid to the structure of overhead transmission lines (OL), because they are the responsible objects of the ENs for the transportation and distribution of electricity. To date, EN is the most vulnerable EN facilities. This is because the lines are long, poorly controlled and interact with the environment, which leads to incomplete information about their parameters and affects the EN effectiveness. Therefore, it is important to study the improvement of the air-line structure for optimal control of the transportation and distribution of electricity in real time.

\section{The object of research and its technological audit}

The object of research is the processes in the overhead lines that affect the transportation and distribution of electricity.

In the past 10 years, to reduce the lack of information on the parameters that affect the operating modes of the overhead line, state programs have been introduced to create various new means of regulating steady-state and transient EN modes. The purpose of such programs is improvement of the efficiency of transportation and distribution of electricity. The result is the concept of Smart Grid [1-3].

State structures in most countries view the Smart Grid as: - the ideology of national programs for development of the electric power industry;

- companies producing equipment and technologies;

- prospective basis of business optimization;

- energy companies;

- basis for ensuring a sustainable innovative modernization of its activities.

And at the first stage for the implementation of the Smart Grid concept it is necessary to streamline the structure of the electric grid equipment, including the $\mathrm{OL}$ structure, in accordance with the required conditions [4].

In the electricity market [4], one of the main tasks of the electric power industry in Ukraine is increasing the efficiency of managing the operation modes of the ES for optimal transport and distribution of electricity from generating sources to consumers.

This direction can be implemented in modern conditions on technical and economic models, taking into account the incompleteness of the initial information, using criteria programming. To search for a rational structure, parametric series are formed. The basis of the OL rational structure is the level of standardization and unification of 
the parametric series of wire cross-sections, which reflects the possibility of using standard design solutions, standard technological processes and standard OL elements.

The foregoing is necessary, but not sufficient, to improve the efficiency of transport and the distribution of electricity.

To realize the full efficiency of transportation and distribution of electric power, it is necessary to provide for equipping the lines with appropriate means for evaluating and controlling the parameters of the object in real time. This does not contradict the Smart Grid platform, which is the main core of modern scientific developments in the field of electric power industry.

Within the framework of the EN innovative modernization, there are already corresponding technical solutions, including a fiber-optic monitoring system for the temperature regime and dimensions (FOMS) of the OL [5]

One of the most problematic places is the wires of overhead lines, because the variety of wires that the lines are made with, leads to network heterogeneity. This is reflected in the technological losses of power and complicates the OL FOMS installation.

\section{The aim and objectives of research}

The aim of research is improvement of the structure of overhead lines for optimal control of transportation and distribution of electricity in real time.

To achieve this aim, it is necessary to solve such problems:

1. To formulate a criterion of technical and economic distinguishability of the OL variants for the formation of a coefficient of increase in the scale of wire cross-sections.

2. To analyze the impact of unification on the schedule of $\mathrm{OL}$ reconstruction.

3. To present, in accordance with the Smart Grid concept, a fiber optic system for continuous temperature monitoring and control of the OL dimensions.

\section{Research of existing solutions of the problem}

The first work to improve the OL structure by optimizing the parametric series of wire cross sections was carried out by scientists back in the 80 s of the last century [6]. In their works they considered the optimization of a parametric series of wire cross sections and provided proposals for lines of $35-750 \mathrm{kV}$. According to the similarity theory, in order to search for the optimal parametric series of wire cross-sections, scientists used the criteria method, which allowed to avoid the lack of information. For this purpose, the technical-economic model of the overhead line was written in the criteria form and analyzed by the criteria method. Such approach allowed to form an expedient optimization parameter in the conditions of functioning of the electric power industry in that period. And since the conditions for the functioning of the electric power industry have changed, it is necessary to revise their recommendations in accordance with modern requirements $[4,7]$.

In [8], a strategy for the development of the electric power industry on the principle of unification and typing of a number of electric grid equipment elements was proposed, but questions of optimization of the parametric series of wire cross-sections are not sufficiently considered.
In $[9,10]$, questions of optimization of the parametric series of wire cross-sections were considered and proposals for the unification of $110-750 \mathrm{kV}$ OL were presented, but prospects for changing electric loads were not taken into account.

In [11] modes of operation of optimization of power systems are considered, but attention to the structure of lines is not accentuated.

The improvement of the OL structure according to the intellectualization of the networks should provide for equipping the facility with appropriate tools for evaluating and monitoring parameters in real time [1, 3, 12]. Equipping the overhead line with appropriate means extends their functionality and is interconnected with the design of the lines. Precisely for this purpose, at the first stage, it is necessary to optimize the parametric series of the OL cross sections.

It is expedient to solve this problem on technical and economic models taking into account the incompleteness of the initial information using criteria programming [13, 14].

Thus, the results of the analysis allow to conclude that it is necessary to solve the problems that determine the appropriate parameters and OL operating modes:

- optimization of the parametric series of wire sections;

- expansion of the OL functionality.

\section{Methods of research}

To optimize the parametric series of wire cross-sections, the technical and economic model of OL discount costs $\left(C_{i}\right)$ has been improved, the main difference of which is the change in the analytical connection of investments in OLS with wire cross-section $(F)$ :

$$
C=K_{0} p_{l} l+K_{u} p_{d} l U_{i}^{\alpha}+K_{F} p_{d} l F+\frac{\mu \rho l P^{2} K_{k}}{U^{2} \cos ^{-2} \varphi F},
$$

where $K_{0}$ - coefficient of the constant component of the cost, which does not depend on the wire cross-section and the line voltage class; $K_{u}$ - coefficient that takes into account the line voltage class; $K_{F}$ - coefficient that takes into account the change in the cost of the line, depending on the wire section; $P_{d}$ - coefficient of deductions, which consists of:

$$
P_{d}=p_{d p}+p_{\text {rand } m}
$$

where $p_{d p}$ - depreciation coefficient; $p_{\text {rand } m}-$ coefficient for repair and maintenance of lines; $F$ - cross-section of the line wire, $\mathrm{mm}^{2} ; \tau$ - time of maximum losses is defined as:

$$
\tau=\left(0.124+T_{\max } / 10^{4}\right)^{2} \cdot 8760,
$$

where $T_{\max }$ - the maximum hour of use, year; $\mu$ - unit cost of electricity losses, c. u./(kW·year); $\rho$ - wire resistivity, $\mathrm{Ohm} \cdot \mathrm{mm}^{2} / \mathrm{km} ; P$ - maximum line power, $\mathrm{MW} ; U-$ line voltage, $\mathrm{kV} ; l$ - line length, $\mathrm{km}$; $\cos \varphi$ - line power factor; $K_{k}$ - the coefficient of corona loss, which consists of:

$$
K_{k}=\left(\tau+K_{r}\right),
$$

where $K_{r}$ - corona loss factor, for $\tau=1000 \div 7000$ (h/year) $K_{r}=0.05 \div 0.15$ and is taken into account only for overhead transmission lines $330-750 \mathrm{kV}$. 
From the point of view of the theory of similarity, the technical and economic OL models are similar. Also, the ratio of the previous discounted costs to the next within the same parametric series is identical. This is a prerequisite for constructing a parametric series of $\mathrm{OL}$ wire cross-sections:

$$
\frac{C_{i i+1}}{C_{\frac{i}{i i-1}}}=\frac{K_{i+1} r_{i}-K_{i} r_{i+1}}{K_{i} r_{i-1}-K_{i-1} r_{i}} \frac{r_{i-1}-r_{i}}{r_{i}-r_{i+1}} \equiv \text { idem, }
$$

where $r_{i}$ - the active resistance of the $i$-th wire; $K_{i}$ - investment in the $i$-th line.

According to the similarity theory, in the first approximation, in order to find the optimal parametric series, a criteria method was used in $[6,10,11]$, which made it possible to avoid the incompleteness and uncertainty of the initial information. For this purpose, the OL technicaleconomic model (1) is written in the criteria form:

$$
C=\pi_{1}^{\prime} F^{\alpha l}+\pi_{2}^{\prime} U^{\alpha}+\pi_{3}^{\prime} U^{-2} F^{-1},
$$

where $\pi_{1}^{\prime}, \pi_{2}^{\prime}, \pi_{3}^{\prime}$ - the similarity criteria that do not depend on the initial information and are determined from the system of equations, the formation of which is based on the orthogonality and normalization conditions at the optimum point [14].

The developed technical-economic model of the overhead line (6) is used to calculate the coefficient of formation of the optimal parametric series of the sections of the overhead lines, provided that two adjacent wires differ from each other by a value that does not exceed the zone of equal economic efficiency. In these studies, an interval of 0.01 to 0.02 is adopted for the zone of equal economic efficiency.

Considering that the wire cross-section is one of the main elements of the overhead line and its optimization is important, since it affects the capacity of the lines, which is reflected in the procedure for the reconstruction of the facility, the frequency affects the operating costs. Therefore, in subsequent studies, using the similarity theory and the obtained coefficient for a given load character, it is revealed that the time to the required reconstruction is relatively similar [13].

For this purpose, as a basis section $F_{b}$, the wire crosssection, taken for the year of construction and commissioning of the overhead line, is taken as the cross section for the reconstruction period of the overhead line, then the ratio:

$$
\frac{F_{2}}{F_{b}}=F
$$

is nothing more than a coefficient of increase in the scale of wire cross-sections.

Let there be two different scales of sections, characterized by the coefficients $F_{1}$ and $F_{2}$. As in the first, and in the second case, the rate of change of loads will be the same. Then according to (7):

$$
P(1+q)^{t_{1}}=F_{*}^{0.625}
$$

and

$$
\underset{*}{P}(1+q)^{t_{2}}=F_{*}^{0.625} .
$$

Relations (8) and (9) can be written in the form:

$$
\begin{aligned}
& \frac{t_{2}}{t_{1}}=\frac{\ln F_{2}}{n F_{1}}=\text { idem, } \\
& t=0.625 \frac{\ln F}{\ln (1+q)} .
\end{aligned}
$$

In this expression, the time $t$ determines the interval from the start of operation to the first reconstruction, which is due to a change in the OL throughput, which depends on the wire cross section $(F)$ and the specified rate of load variation $(q)$.

\section{Research results}

Analysis of the model (6) by the criteria method [14] shows that, depending on the error of the initial information, it is possible to obtain in the first approximation the coefficient of formation of the optimum wire crosssection scale.

The results of the justification of the optimality coefficient of the parametric series of the cross sections of the overhead lines:

$$
\begin{array}{cllllllllll}
\delta, \% & \pm 1 & \pm 2 & \pm 3 & \pm 4 & \pm 5 & \pm 6 & \pm 7 & \pm 8 & \pm 9 & \pm 10 \\
F_{0} & 2.0 & 2.0 & 2.02 & 2.02 & 2.03 & 2.04 & 2.06 & 2.08 & 2.10 & 2.12
\end{array}
$$

As studies have shown, when the optimal parametric series of wires cross-sections are substantiated, the error of performance characteristics and the most acceptable coefficient play an important role.

Using (8) and (9), it is determined that the reconstruction time, which is due to the OL capacity and the change in the load $q$ at $P_{0}=1$, since it refers to the beginning of OL operation, will be:

$$
t_{0}=0.625 \frac{\ln F}{\ln (1+q)} .
$$

A obtained similar relation:

$$
\frac{t_{2}}{t_{1}}=\frac{\ln 2}{\ln 1.4}=2 \text {. }
$$

Calculation results show that the period to the required reconstruction increases by a factor of 2 if the wire crosssection scale with a coefficient of 2 is used, which, accordingly, reduces the periodicity of the OL reconstruction.

One of the options that allow to extend the OL functionality is the fiber optic monitoring system (FOMS). The control and measuring FOMS element is a fiber-optic cable (FOC) built into the phase conductor. The arrangement of the FOC inside one of the aluminum wires allows for continuous temperature monitoring and control over the dimensions of the overhead line. The optical fiber of the distributed sensor $\mathrm{OK}$ is connected to the measuring unit. The graphic interface of the system allows to split the line of the line into sections, each of which corresponds to certain characteristics of the overhead line. The built-in feature monitoring feature allows to continuously 
monitor the accuracy of measurements and store these indicators for later analysis [5].

\section{SWOT analysis of research results}

Strengths. In comparison with similar results of studies of other scientists, the obtained results comprehensively substantiate the improvement of the OL structure for optimal control of the transportation and distribution of electricity in real time.

The efficiency of the presented direction provides:

- reduction of the terms of development and construction

of overhead lines by using a limited number of supports, foundations, grades of wires, insulation and fittings;

- carrying out of the qualitative control of reliability at their manufacturing;

- reduction of staff errors during the construction and operation of overhead lines;

- reduction of the operational reserve of individual elements of overhead lines;

- reduction in the cost of constructing overhead lines due to competition between individual manufacturers of OL elements;

- ability to monitor the current technical condition of the facility;

- to perform an assessment of the limiting values of long-term and short-time load currents;

- to control the current load modes of the overhead line;

- to regulate the power flow over the overhead line in accordance with the real data on the thermal resistance of the overhead lines.

Weaknesses. Unification of overhead lines allows to solve to a certain extent the issues of the regulation of reconstruction, which is connected with changing the network capacity. This is important for the intellectualization of electricity transmission, but does not expand the functionality of the overhead line.

The use of the WOCM on the basis of unification to expand the functionality of the AL increases the investment.

Opportunities. The proposed integrated approach will reduce the operational costs for the maintenance of the facility through optimal management of transportation and distribution of electricity in real time.

Threats. The introduction of the proposed way to improve the lines in the electric power industry requires the specification of project normative documents. This is due to a change in the ratio of components in the technical and economic model of the lines - investment increases and operating costs are reduced.

\section{Conclusions}

1. The criterion of technical and economic distinguishability of OL variants is formed and the coefficient of growth of the wire cross-section scale is obtained by the criteria method. This coefficient reduces the influence of network heterogeneity and does not contradict unification.

2. The effect of unification on the procedure for the $\mathrm{OL}$ reconstruction is analyzed. It is revealed that the period to the required reconstruction is increased by 2 times if the wire cross-section scale with a coefficient of 2 is used.

3. The fiber-optic system for continuous temperature monitoring and control of the dimensions of overhead lines is presented. This allows to extend the functionality of the object in accordance with the Smart Grid concept.

\section{References}

1. Buchholz B. M., Styczynski Z. Vision and Strategy for the Electricity Networks of the Future // Smart Grids - Fundamentals and Technologies in Electricity Networks. Berlin: Springer, 2014. P. 1-17. doi:10.1007/978-3-642-45120-1 1

2. Intelektualni elektrychni merezhi: elementy ta rezhymy / $\mathrm{Ba}$ ziuk T. M. et al.; ed. by Kyrylenko O. V. Kyiv: Institute of Electrodynamics of the National Academy of Sciences of Ukraine, 2016. $400 \mathrm{p}$.

3. Kobets B. B., Volkova I. O. Smart Grid v elektroenergetike // Energeticheskaya politika. 2009. Vol. 6. P. 54-56.

4. Pro rynok elektrychnoi enerhii Ukrainy: Law of Ukraine from No. 2019-VIII April 13, 2017 / Baza danykh «Zakonodavstvo Ukrainy». URL: http://zakon2.rada.gov.ua/laws/show/2019-19

5. DITEST STA-R series fiber optic distributed strain and temperature analyzer. URL: http://www.omnisens.com/ditest/

6. Standardization of Overhead Power Supply Lines // Nature 1943. Vol. 151, No. 3833. P. 445-446. doi:10.1038/151445fo

7. Lucheroni C. Resonating models for the electric power market // Physical Review E. 2007. Vol. 76, No. 5. doi:10.1103/ physreve.76.056116

8. Rao G. S. Unification of DG units to the electrical network. LAP LAMBERT Academic Publishing, 2015. 112 p.

9. Faybisovich D. L. Predlozheniya po unifikatsii secheniy provodov vozdushnykh liniy napryazheniem $110-750 \mathrm{kV} / /$ Energetik. 2003. Vol. 3. P. 21-22

10. Lezhniuk P. D., Cheremisin M. M., Cherkashyna V. V. Unifikatsiia povitrianykh linii $\mathrm{v}$ umovakh rynku dvostoronnikh dohovoriv ta balansuvalnoho rynku elektroenerhii // Naukovi pratsi VNTU. 2013. Vol. 4. P. 1-8.

11. Zhu J. Optimization of Power System Operation. Piscataway: Wiley-IEEE Press, 2015. 623 p.

12. Dimtriev S. A., Slepov N. N. Volokonno-opticheskaya tekhnika: sovremennoe sostoyanie i perspektivy. Moscow: Volokonnoopticheskaya tekhnika, 2005. $576 \mathrm{p}$.

13. Cherkashyna V. V. Faktor vremeni v strategii usovershenstvovaniya elektricheskikh setey // Elektrotekhnika i Elektromekhanika. 2014. Vol. 3. P. 65-68.

14. Cheremisin N. M., Cherkashyna V. V. Kriterial'nyy metod analiza tekhniko-ekonomicheskikh zadach v elektricheskikh setyakh i sistemakh: handbook. Kharkiv: Fakt, 2014. 96 p.

Cherkashyna Veronika, PhD, Associate Professor, Department of Transmissions of Electric Energy, National Technical University «Kharkiv Polytechnic Institute», Ukraine, e-mail: cherk34@rambler.ru, ORCID: https://orcid.org/0000-0002-5639-9722 